\title{
HUBUNGAN OLAHRAGA DAN MOTIVASI BELAJAR DENGAN KONSENTRASI BELAJAR PADA MAHASISWA FAKULTAS KEDOKTERAN UMUM UNIVERSITAS MALAHAYATI
}

\author{
Vira Sandayanti ${ }^{1}$, Nopi Sani ${ }^{2}$, Achmad Farich ${ }^{3}$, Selly Oktaviani ${ }^{1}$ \\ ${ }^{1}$ Program Studi Psikologi Fakultas Kedokteran Universitas Malahayati \\ ${ }^{2}$ Departemen Biokimia Fakultas Kedokteran Universitas Malahayati \\ ${ }^{3}$ Fakultas Kesehatan Masyarakat Universitas Malahayati \\ [email korespondensi: sellyoktaviani1827@gmail.com]
}

\begin{abstract}
Relationship of Sport and Study Motivation with Learning Concentration in Students of The Faculty of General Medicine, Malahayati University. Learning concentration is the concentration of attention in the behavior change process which is expressed in the form of mastery, use, and assessment of or regarding attitudes and values, basic knowledge and skills found in various fields of. There are many factors that affect a person's learning concentration, including sports / physical activity factors and learning motivation factors. The purpose of this study was to determine the relationship between sports and learning motivation and learning concentration in students of the General Medicine Faculty of Malahayati University. This type of research was an observational analytic study with cross sectional method using purposive sampling totaling 180 samples. Data collection began in January-February 2021. This research was conducted online using google form. The statistical data of test Spearmans used SPSS 26. Research respondents were found, totaling 180 respondents with low learning concentration totaling 19 respondents $(10.6 \%)$, moderate learning concentration totaling 100 respondents $(55.6 \%)$ and heavy learning concentration totaling 61 respondents (33.9\%). Respondents with light physical activity totaled 40 respondents $(22.2 \%)$, moderate physical activity totaled 133 respondents $(73.9 \%)$ and heavy physical activity totaled 7 respondents $(3.9 \%)$. Respondents with low learning motivation were 0 respondents $(0 \%)$, moderate learning motivation was 74 respondents $(41.1 \%)$ and high learning motivation was 106 respondents (58.9\%). There was a relationship between sports and learning concentration at the university's general medical faculty, and there is a relationship between learning motivation and learning concentration at the General Medicine Faculty of Malahayati University.

Keywords: Sports, Learning Motivation, Concentration of Learning
\end{abstract}

\begin{abstract}
Abstrak: Hubungan Olahraga dan Motivasi Belajar dengan Konsentrasi Belajar pada Mahasiswa Fakultas Kedokteran Umum Universitas Malahayati. Konsentrasi belajar adalah pemusatan perhatian dalam proses Perubahan tingkah laku yang dinyatakan dalam bentuk penguasaan, penggunaan, dan penilaian terhadap atau mengenai sikap dan nilai-nilai, pengetahuan dan kecakapan dasar yang terdapat dalam berbagai bidang studi. Banyak faktor yang mempengaruhi konsentrasi belajar seseorang yaitu faktor internal dan faktor eksternal diantaranya ada olahraga/aktivitas fisik dan motivasi belajar. Tujuan penelitian ini adalah diketahui hubungan olahraga dan motivasi belajar dengan konsentrasi belajar pada Mahasiswa Fakultas Kedokteran Umum Universitas Malahayati. Jenis Penelitian ini adalah analitik observasional dengan metode cross sectional menggunakan purposive sampling sebanyak 180 sampel keseluruhan. Pengambilan data dimulai pada bulan Januari-Februari 2021. Penelitian ini dilakukan secara online dengan menggunakan google form. Data statistik uji Spearmans menggunakan SPSS 26. Didapatkan responden penelitian, berjumlah 180 responden dengan Konsentrasi belajar rendah berjumlah 19 responden $(10.6 \%)$, Konsentrasi belajar sedang berjumlah 100 responden (55.6\%) dan Konsentrasi belajar berat berjumlah 61 responden (33.9\%). Responden dengan
\end{abstract}


dengan Aktivitas fisik ringan berjumlah 40 responden (22.2\%), Aktivitas fisik sedang berjumlah 133 responden (73.9\%) dan aktivitas fisik berat berjumlah 7 responden $(3.9 \%)$. Responden dengan motivasi belajar rendah berjumlah 0 responden $(0 \%)$, motivasi belajar sedang berjumlah 74 responden $(41.1 \%)$ dan motivasi belajar tinggi berjumlah 106 responden (58.9\%). Terdapat hubungan olahraga dengan konsentrasi belajar pada Fakultas Kedokteran Umum Universitas Malahayati, dan terdapat hubungan motivasi belajar dengan konsentrasi belajar pada Fakultas Kedokteran Umum Universitas Malahayati.

Kata Kunci: Olahraga, Motivasi Belajar, Konsentrasi Belajar

\section{PENDAHULUAN}

Belajar adalah perubahan tingkah laku sebagai akibat dari adanya interaksi antara stimulus dan respon. Dengan kata lain, belajar merupakan bentuk perubahan yang dialami seseorang dalam hal kemampuannya untuk bertingkah laku dengan cara yang baru sebagai hasil interaksi antara stimulus dan respon. Seseorang dianggap telah belajar sesuatu apabila ia dapat menunjukkan perubahan tingkah lakunya secara dinamis dan baik. Menurut teori ini yang terpenting adalah masukan atau input yang berupa stimulus dan keluaran atau output yang berupa respon (Ferdiyanto dkk, 2019).

Banyak faktor yang mempengaruhi proses belajar dan mengajar salah satunya adalah faktor konsentrasi. Konsentrasi adalah salah satu faktor utama yang dapat mempengaruhi pembelajaran. Semakin tinggi konsentrasi seseorang maka semakin efektif kegiatan pembelajaran tersebut, namun sebaliknya jika konsentrasi rendah maka hasil yang diperolehnya pun tidak maksimal (Pratama dkk, 2017).

Memiliki konsentrasi yang baik tentunya harus mempunyai tingkat kebugaran yang baik karena ketika seseorang tidak memiliki tingkat kebugaran jasmani yang baik kemungkinan orang tersebut akan mudah untuk merasakan lelah dan akan mudah terkena penyakit, sehingga tingkat kesehatannya akan berdampak pada konsentrasi belajar dan prestasi akademik yang akan diraih. Tingkat kebugaran jasmani sangat diperlukan untuk mendukung aktivitas sehari-hari sehingga seseorang memiliki tingkat kebugaran yang baik maka tidak akan memiliki kelelahan yang berarti. Oleh karena itu, semua aktivitas manusia menuntut kebugaran jasmani (Cahyani dkk, 2016).

Olahraga adalah kegiatan pelatihan jasmani, yaitu kegiatan jasmani untuk memperkaya dan meningkatkan kemampuan dan keterampilan gerak dasar maupun gerak keterampilan (kecabangan olahraga). Kegiatan itu merupakan bentuk pendekatan ke aspek sejahtera jasmani atau sehat jasmani yang berarti juga sehat dinamis yaitu sehat yang disertai dengan kemampuan gerak yang memenuhi segala tuntutan gerak kehidupan sehari-hari. Artinya setiap orang yang melakukan pendidikan jasmani melalui aktivitas olahraga dan memiliki tingkat kebugaran jasmani yang memadai (Bangun, 2016).

Berdasarkan penelitian yang dilakukan oleh Santoso dan Anandaputra (2017) tentang "Hubungan Intensitas Olahraga dengan Daya Konsentrasi Belajar Siswa/Siswi Kelas 10 dan 11 SMAN 5 Depok Jawa Barat" menyatakan bahwa hasil uji statistik pada 121 siswa yang sering melakukan kegiatan olahraga didapatkan $86 \%$ memiliki daya konsentrasi belajar yang baik dan 14\% kurang baik. Lalu dari 155 siswa yang jarang berolahraga, didapatkan $74.8 \%$ memiliki daya konsentrasi yang baik dan $31.4 \%$ kurang baik.

Motivasi belajar adalah

keseluruhan daya penggerak di dalam diri siswa yang menimbulkan kegiatan belajar, yang menjamin kelangsungan dari kegiatan belajar dan yang memberikan arah pada kegiatan belajar, sehingga tujuan yang dikehendaki oleh subjek belajar itu dapat tercapai. Motivasi belajar merupakan faktor psikis yang bersifat non intelektual. Peranannya yang khas adalah dalam hal penumbuhan gairah, merasa senang 
dan semangat untuk belajar. Siswa yang memiliki motivasi kuat, akan mempunyai banyak energi untuk melakukan kegiatan belajar (Sardiman, 2016).

Hasil penelitian sebelumnya yang dilakukan (Nasution, 2018) dengan judul penelitian "Hubungan antara Motivasi Belajar dengan Konsentrasi Belajar Siswa" memperlihatkan bahwa: (1) motivasi belajar siswa berada pada kategori tinggi (persentase rata-rata $71.25 \%)$, (2) konsentrasi belajar siswa berada pada kategori tinggi (persentase rata-rata $69.83 \%$ ), (3) dan terdapat hubungan positif yang signifikan antara motivasi belajar dengan konsentrasi belajar siswa dengan koefisien korelasi 0.753 dan taraf signifikansi 0.000 .

\section{METODE}

Jenis penelitian ini adalah analitik observasional dengan metode cross sectional menggunakan purposive sampling sebanyak 180 sampel keseluruhan. Pengambilan data dimulai pada bulan Januari-Februari 2021. Data yang digunakan yaitu data primer berupa kuesioner IPAQ (International Physical Activity Questionnaire), kuesioner motivasi belajar dan kuesioner konsentrasi belajar. Penelitian ini dilakukan secara online menggunakan google form.

Analisis data menggunakan uji Spearman pada aplikasi SPSS 26 dengan tingkat kemaknaan pada penelitian ini ditetapkan dengan nilai $\mathrm{p}$ $<0.05$. Adapun uji statistik yang digunakan adalah uji koreasi Spearman karena data uji normalitas tidak terdistribusi normal.

\section{HASIL}

Berdasarkan penelitian di atas responden berdasarkan jenis kelamin menunjukan bahwa dari subjek penelitian sebanyak 180 orang didapat responden terbanyak berjenis kelamin perempuan berjumlah 136 orang (75.6\%) sedangkan laki- laki berjumlah 44 orang (24.4\%). Dan karakteristik berdasarkan usia yang terbanyak pada usia 21 tahun (58.3\%) kemudian yang paling sedikit pada usia 19 tahun sebanyak $0.6 \%$.

Tabel 1. Distribusi Frekuensi Olahraga pada Mahasiswa Fakultas Kedokteran Umum Universitas Malahayati Angkatan 2017

\begin{tabular}{lll}
\hline Olahraga & Frekuensi & Presentase \\
\hline Aktivitas Ringan & 40 & $22.2 \%$ \\
Aktivitas Sedang & 133 & $73.9 \%$ \\
Aktivitas Berat & 7 & $3.9 \%$ \\
\hline Total & $\mathbf{1 8 0}$ & $\mathbf{1 0 0 . 0} \%$ \\
\hline
\end{tabular}

Tabel 1 menunjukkan bahwa distribusi frekuensi tingkat olahraga pada mahasiswa Fakultas Kedokteran Universitas Malahayati angkatan 2017. Didapatkan hasil yang melakukan aktivitas fisik ringan sebanyak 40 mahasiswa (22.2\%), dan 133 mahasiswa (73.9\%) yang melakukan aktivitas fisik sedang serta 7 mahasiswa $(3.9 \%)$ yang melakukan aktivitas fisik berat.

Tabel 2. Distribusi Frekuensi Motivasi Belajar pada Mahasiswa Fakultas Kedokteran Umum Universitas Malahayati Angkatan 2017

\begin{tabular}{lll}
\hline Motivasi Belajar & Frekuensi & Presentase \\
\hline Rendah & 0 & $0 \%$ \\
Sedang & 74 & $41.1 \%$ \\
Tinggi & 106 & $58.9 \%$ \\
\hline Total & $\mathbf{1 8 0}$ & $\mathbf{1 0 0 . 0 \%}$ \\
\hline
\end{tabular}


Tabel 2 menunjukkan bahwa distribusi frekuensi tingkat motivasi belajar pada mahasiswa Fakultas Kedokteran Universitas Malahayati angkatan 2017 didapatkan hasil tidak ada yang memiliki motivasi belajar rendah $(0 \%)$, motivasi belajar sedang sebanyak 74 mahasiswa atau (41.1\%), dan untuk motivasi belajar tinggi sebanyak 106 mahasiswa atau (58.9\%).

Tabel 3. Distribusi Frekuensi Konsentrasi Belajar pada Mahasiswa Fakultas Kedokteran Umum Universitas Malahayati Angkatan 2017

\begin{tabular}{lll}
\hline Konsentrasi Belajar & Frekuensi & Presentase \\
\hline Rendah & 19 & $10.6 \%$ \\
Sedang & 100 & $55.6 \%$ \\
Tinggi & 61 & $33.9 \%$ \\
\hline Total & $\mathbf{1 8 0}$ & $\mathbf{1 0 0 . 0} \%$ \\
\hline
\end{tabular}

Tabel 3 menunjukkan bahwa distribusi frekuensi tingkat konsentrasi belajar pada mahasiswa Fakultas Kedokteran Universitas Malahayati angkatan 2017 didapatkan hasil konsentrasi belajar rendah sebanyak 19 mahasiswa atau (10.6\%), konsentrasi belajar sedang sebanyak 100 mahasiswa atau (55.6\%), dan untuk konsentrasi belajar tinggi sebanyak 61 mahasiswa atau $(33.9 \%)$.

Tabel 4. Hubungan Olahraga dengan Konsentrasi Belajar pada Mahasiswa Fakultas Kedokteran Umum Universitas Malahayati Angkatan 2017

\begin{tabular}{cccc}
\hline $\begin{array}{c}\text { Konsentrasi } \\
\text { belajar }\end{array}$ & N & P Value & Cor.Coefficient \\
\hline Olahraga & 180 & 0.000 & 0.484 \\
\hline
\end{tabular}

Berdasarkan tabel 4, didapatkan angka koefisien sebesar 0.484 dengan $P$ value $0.000<0.05$. Dapat disimpulkan bahwa ada hubungan yang bermakna antara olahraga dengan konsentrasi belajar pada mahasiswa fakultas kedokteran umum Universitas Malahayati. Nilai korelasi $r=0.484$, artinya kekuatan korelasi sedang yaitu dengan rentang 0.40-0.599. Hubungan antara olahraga dan konsentrasi belajar memiliki tanda positif menunjukkan adanya hubungan yang searah, artinya semakin meningkat olahraga maka konsentrasi belajar juga akan meningkat.

Tabel 5. Hubungan Motivasi Belajar dengan Konsentrasi Belajar pada Mahasiswa Fakultas Kedokteran Umum Universitas Malahayati Angkatan 2017

\begin{tabular}{cccc}
\hline $\begin{array}{c}\text { Konsentrasi } \\
\text { belajar }\end{array}$ & N & P Value & Cor.Coefficient \\
\hline Motivasi Belajar & 180 & 0.000 & 0.262 \\
\hline
\end{tabular}

Tabel 5 Didapatkan angka koefisien sebesar 0,262 dengan $P$ value $0.000<0.05$. Dapat disimpulkan bahwa ada hubungan yang bermakna antara motivasi belajar dengan konsentrasi belajar pada mahasiswa fakultas kedokteran umum Universitas Malahayati. Nilai korelasi $r=0.262$, artinya kekuatan korelasi rendah yaitu dengan rentang $0.20 \quad-0.399$. Hubungan antara motivasi belajar dan konsentrasi belajar memiliki tanda positif menunjukkan adanya hubungan yang searah, artinya semakin meningkat motivasi belajar maka konsentrasi belajar juga akan meningkat. 


\section{PEMBAHASAN}

Berdasarkan hasil penelitian diatas didapatkan gambaran tingkat olahraga pada Mahasiswa Fakultas Kedokteran Umum Universitas Malahayati angkatan 2017 pada hasil penelitian ini diketahui bahwa yang melakukan aktivitas fisik ringan sebanyak 40 mahasiswa $(22.2 \%)$, dan 133 mahasiswa (73.9\%) yang melakukan aktivitas fisik sedang serta 7 mahasiswa $(3.9 \%)$ yang melakukan aktivitas fisik berat dengan keterangan sering dan jarang berolahraga berdasarkan frekuensi dan durasi olahraga yang dilakukan dalam waktu seminggu, dapat disimpulkan bahwa responden masih aktif dalam berolahraga dirumah dan di waktu luang.

Hal ini sejalan dengan teori Bangun (2016) yang menyatakan bahwa Olahraga adalah kegiatan pelatihan jasmani, yaitu kegiatan jasmani untuk memperkaya dan meningkatkan kemampuan dan keterampilan gerak dasar maupun gerak keterampilan (kecabangan olahraga). Artinya setiap orang yang melakukan pendidikan jasmani melalui aktivitas olahraga dan memiliki tingkat kebugaran jasmani yang memadai.

Hasil penelitian sebelumnya oleh Santoso dan Anandaputra (2017) menunjukkan $43.8 \%$ siswa/siswi sering berolahraga dan $56.2 \%$ jarang berolahraga. Keterangan sering dan jarang berolahraga berdasarkan frekuensi dan durasi olahraga yang dilakukan dalam waktu seminggu selain di waktu pelajaran olahraga contohnya adalah kegiatan ekstrakurikuler dan juga kegiatan olahraga dirumah dan di waktu luang. Intensitas olahraga siswa/siswi SMAN 5 Depok memiliki nilai yang hampir seimbang.

Peneliti menyimpulkan bahwa tingkat olahraga pada Mahasiswa Fakultas Kedokteran Umum Universitas Malahayati angkatan 2017 terbanyak adalah aktivitas fisik sedang berarti mahasiswa sudah melakukan aktivitas fisik dalam satu minggu terakhir dengan intensitas dan durasi yang berbeda. Seseorang yang sering berolahraga dan beraktivitas fisik memiliki kemampuan kognitif ataupun intelegensi yang lebih baik dibandingkan yang jarang berolahraga maupun yang tidak berolahraga

Tingkat motivasi belajar pada Mahasiswa Fakultas Kedokteran Umum Universitas Malahayati Angkatan 2017 pada hasil penelitian ini diketahui bahwa tidak ada yang memiliki motivasi belajar rendah $(0 \%)$, motivasi belajar sedang sebanyak 74 mahasiswa atau (41.1\%), dan untuk motivasi belajar tinggi sebanyak 106 mahasiswa atau (58.9\%). Motivasi belajar adalah keseluruhan daya penggerak di dalam diri yang menimbulkan kegiatan belajar, yang menjamin kelangsungan dari kegiatan belajar dan memberi arah pada kegiatan belajar, sehingga tujuan yang dikehendaki itu dapat tercapai (Sardiman, 2016).

Aspek-aspek motivasi belajar antara lain ketekunan dalam belajar, ulet dalam menghadapi kesulitan, minat dan ketajaman perhatian dalam belajar, berprestasi dalam belajar, dan mandiri dalam belajar (Sardiman, 2016). Oleh sebab itu, mahasiswa dengan aspekaspek motivasi belajar yang tinggi menunjukkan bahwa mahasiswa tersebut memiliki motivasi belajar yang tinggi, mahasiswa dengan aspek-aspek motivasi belajar tersebut namun belum optimal menunjukkan bahwa mahasiswa tersebut memiliki motivasi belajar yang sedang, dan mahasiswa yang tidak memiliki aspek-aspek motivasi belajar tersebut menunjukkan bahwa mahasiswa tersebut memiliki motivasi belajar yang rendah.

Hasil penelitian sebelumnya yang dilakukan (Mukhtar, 2015) bahwa hasil rata-rata/mean motivasi belajar siswa kelas X SMA Piri 1 Yogyakarta adalah 60.77 atau dalam kategori sedang. Motivasi belajar yang tinggi tercermin dari ketekunan yang tidak mudah patah untuk mencapai sukses meskipun dihadang oleh berbagai kesulitan. Motivasi yang tinggi dapat menggiatkan aktivitas belajar siswa. Siswa yang mempunyai motivasi tinggi akan melaksanakan kegiatan belajarnya 
dengan penuh keyakinan, konsentrasi yang baik dan tanggung jawab bila dibandingkan dengan siswa yang memiliki motivasi belajar rendah, sehingga akan mencapai hasil belajar yang optimal.

Berdasarkan hasil diatas peneliti menyimpulkan bahwa tingkat motivasi belajar pada Mahasiswa Fakultas Kedokteran Umum Universitas Malahayati angkatan 2017 terbanyak adalah motivasi belajar tinggi berarti mahasiswa sudah memiliki semangat yang tinggi untuk belajar dan akan berpengaruh pada konsentrasi belajar mahasiswa.

Tingkat konsentrasi belajar pada Mahasiswa Fakultas Kedokteran Umum Universitas Malahayati Angkatan 2017 pada hasil penelitian ini diketahui bahwa konsentrasi belajar rendah sebanyak 19 mahasiswa atau (10.6\%), konsentrasi belajar sedang sebanyak 100 mahasiswa atau $(55.6 \%)$, dan untuk konsentrasi belajar tinggi sebanyak 61 mahasiswa atau (33.9\%).

Sejalan dengan teori (Sagareno, 2020) bahwa konsentrasi tingkat sedang menunjukkan bahwa pada saat belajar, konsentrasi mahasiswa pada objek yang dipelajari tidak sepenuhnya terpusat karena "secara bersamaan" terdapat emosi lain yang mengganggu pikiran saat berkonsentrasi seperti perasaan sedih, marah, takut, ataupun khawatir yang timbul karena permasalahan pada kehidupan sehari hari.

Berbagai macam emosi yang mengganggu pikiran mahasiswa untuk berkonsentrasi menurut Bocar \& Tizon (2017) dalam Sagareno, 2020 di antaranya disebabkan oleh; banyaknya tugas yang harus segera dikerjakan dan dikirim (melalui email), terlalu banyak memikirkan agenda selanjutnya, selain itu juga adanya permasalahan di lingkungan tempat tinggal, memiliki hubungan yang buruk dengan orang tua dan mendapatkan mendapatkan perlakuan kekerasan dari orang tua, berselisih dan terlibat perkelahian dengan teman di kampus, dan putusnya hubungan dengan pacar.
Hasil penelitian sejalan dengan penelitian yang dilakukan oleh (Sagareno, 2020) didapatkan hasil analisis univariat mahasiswa kedokteran universitas lampung $77.6 \%$ masuk kategori konsentrasi tingkat sedang dan $65.8 \%$ masuk kategori adiksi ponsel pintar berdasarkan hasil analisis bivariate didapatkan $\mathrm{d}=\mathbf{- 0 . 2 1 4}$ $(p<0,005)$.

Berdasarkan hasil penelitian diatas peneliti menyimpulkan bahwa mahasiswa Fakultas Kedokteran Universitas Malahayati sebagian besar memiliki tingkat konsentrasi sedang sebanyak (55.6\%) dan memberikan gambaran bahwa mahasiswa mampu memusatkan perhatian pada objek yang sedang dipelajari namun tidak sepenuhnya mampu menyingkirkan distraksi yang mengganggu pikiran.

Hubungan Olahraga dengan Konsentrasi Belajar pada Mahasiswa Fakultas Kedokteran Umum Universitas Malahayati Angkatan 2017 pada hasil penelitian ini diketahui bahwa angka koefisien sebesar 0.484 dengan $P$ value $0.000<0.05$. Dapat disimpulkan bahwa ada hubungan yang bermakna antara olahraga dengan konsentrasi belajar dengan kekuatan korelasi sedang. Hubungan antara olahraga dan konsentrasi belajar memiliki tanda positif menunjukkan adanya hubungan yang searah, artinya semakin meningkat olahraga maka konsentrasi belajar juga akan meningkat.

Hal ini sesuai dengan teori yang mengatakan bahwa seseorang yang sering berolahraga memiliki fungsi metabolisme yang lebih baik dibandingkan seseorang yang jarang berolahraga atau pun yang tidak sama sekali berolahraga. Olahraga dapat memperlancar sistem sirkulasi sehingga kebutuhan nutrisi dan energi untuk otak tercukupi dan membuat otak dapat bekerja secara maksimal (Guyton, 2012).

Berdasarkan

penelitian sebelumnya yang dilakukan oleh Santoso dan Anandaputra (2017), Hasil uji statistik 121 siswa yang sering melakukan olahraga didapatkan $86 \%$ memiliki daya konsentrasi belajar yang 
baik dan 14\% kurang. Lalu dari 155 siswa yang jarang berolahraga, didapatkan $74.8 \%$ memiliki daya konsentrasi yang baik dan $31.4 \%$ kurang. Hasil Bivariat ini dikatakan bermakna dikarenakan $P$ value $<0.05$ dan odd ratio CI 95\%: 1.096 - 3.855 . Melakukan olahraga dengan rutin dan teratur dapat berpengaruh terhadap daya konsentrasi belajar siswa/siswi SMAN 5 Depok.

Berdasarkan hasil penelitian diatas peneliti menyimpulkan bahwa olahraga dapat mempengaruhi konsentrasi belajar mahasiswa karena dilihat dari segi manfaatnya, olahraga atau aktivitas fisik memiliki manfaat tidak hanya untuk menyehatkan tubuh tetapi juga dapat menyehatkan pikiran, sehingga dapat meningkatkan konsentrasi belajar.

$$
\text { Hubungan Motivasi Belajar }
$$

dengan Konsentrasi Belajar pada Mahasiswa Fakultas Kedokteran Umum Universitas Malahayati Angkatan 2017 pada hasil penelitian ini diketahui bahwa angka koefisien sebesar 0.262 dengan $P$ value $0.000<0.05$. Dapat disimpulkan bahwa ada hubungan yang bermakna antara motivasi belajar dengan konsentrasi belajar pada mahasiswa fakultas kedokteran umum Universitas Malahayati dengan kekuatan korelasi rendah 2.62\%. Hubungan antara motivasi belajar dan konsentrasi belajar memiliki tanda positif a adanya hubungan yang searah, artinya semakin meningkat motivasi belajar maka konsentrasi belajar juga akan meningkat.

Sesuai dengan teori Mukhtar (2015) bahwa motivasi belajar yang tinggi tercermin dari ketekunan yang tidak mudah patah untuk mencapai sukses meskipun dihadang oleh berbagai kesulitan. Motivasi yang tinggi dapat menggiatkan aktivitas belajar siswa. Siswa yang mempunyai motivasi tinggi akan melaksanakan kegiatan belajarnya dengan penuh keyakinan dan tanggung jawab bila dibandingkan dengan siswa yang memiliki motivasi belajar rendah, sehingga akan mencapai hasil belajar yang optimal. Hasil penelitian sebelumnya yang dilakukan (Nasution, 2018) dengan judul penelitian "Hubungan antara Motivasi Belajar dengan Konsentrasi Belajar Siswa" memperlihatkan bahwa: (1) motivasi belajar siswa berada pada kategori tinggi (persentase rata-rata $71,25 \%)$, (2) konsentrasi belajar siswa berada pada kategori tinggi (persentase rata-rata 69,83\%), (3) dan terdapat hubungan positif yang signifikan antara motivasi belajar dengan konsentrasi belajar siswa dengan koefisien korelasi 0,753 dan taraf signifikansi 0,000.

Berdasarkan hasil penelitian peneliti menyimpulkan bahwa motivasi belajar mempengaruhi konsentrasi belajar, karena jika mahasiswa memiliki motivasi belajar tinggi maka akan mempunyai peluang besar untuk memperoleh konsentrasi belajar yang lebih baik dibandingkan mahasiswa yang memiliki motivasi belajar rendah.

\section{KESIMPULAN}

Berdasarkan hasil analisis dan pembahasan penelitian, maka dapat diambil kesimpulan mengenai hubungan olahraga dan motivasi belajar dengan konsentrasi belajar pada mahasiswa Fakultas Kedokteran Umum Universitas Malahayati angkatan 2017 diketahui dari hasil penelitian menunjukkan bahwa tingkat olahraga atau aktivitas fisik pada mahasiswa Fakultas Kedokteran Umum Universitas Malahayati angkatan 2017 sebagian besar memiliki aktivitas fisik sedang.

Diketahui dari hasil penelitian menunjukkan bahwa motivasi belajar pada mahasiswa Fakultas Kedokteran Umum Universitas Malahayati angkatan 2017 sebagian besar memiliki motivasi belajar yang tinggi.

Mahasiswa Fakultas Kedokteran Umum Universitas Malahayati angkatan 2017 sebagian besar memiliki tingkat konsentrasi belajar sedang. Terdapat hubungan antara olahraga dan konsentrasi belajar pada mahasiswa Fakultas Kedokteran Umum Universitas Malahayati angkatan 2017.

Terdapat hubungan motivasi belajar dengan konsentrasi belajar pada mahasiswa Fakultas Kedokteran Umum Universitas Malahayati angkatan 2017. 


\section{SARAN}

Berdasarkan hasil penelitian diketahui bahwa olahraga dan motivasi belajar mempunyai peran penting dalam mempengaruhi konsentrasi belajar. Maka dari itu peneliti lain dapat melakukan penelitian serupa di waktu, tempat, atau teknik penelitian yang berbeda untuk mengetahui faktor-faktor yang mempengaruhi konsentrasi belajar pada mahasiswa. Penelitian ini tidak bisa dilakukan secara langsung dikarenakan terhalang karena pandemi Covid-19 dan diharapkan peneliti selanjutnya bisa melakukan penelitian secara langsung ke responden sehingga dapat melihat langsung responden mengisi kuesioner.

Berdasarkan hasil penelitian diketahui bahwa olahraga dan motivasi belajar mempunyai peran penting dalam mempengaruhi konsentrasi belajar, diharapkan mahasiswa dapat mempelajari hasil penelitian ini dan menerapkannya dalam kegiatan seharihari, dan disarankan untuk meningkatkan konsentrasi belajar dengan memperhatikan dan mengikuti pembelajaran dengan sungguh-sungguh serta selalu berperan aktif contohnya seperti bertanya saat proses pembelajaran yang sedang berlangsung, serta dapat meningkatkan intensitas olahraga dan juga aktivitas fisiknya dirumah, maupun di waktu luangnya.

Berdasarkan hasil penelitian diketahui bahwa olahraga dan motivasi belajar mempunyai peran penting dalam mempengaruhi konsentrasi belajar, oleh karena itu institusi diharapkan dapat membantu dalam menyelenggarakan seminar-seminar mengenai motivasi untuk menambah motivasi belajar guna meningkatkan konsentrasi belajar mahasiswa serta mengadakan gerakan masyarakat (GERMAS) secara rutin untuk meningkatkan aktivitas fisik mahasiswa.

\section{DAFTAR PUSTAKA}

Bangun, S. Y. (2016). Peran Pendidikan Jasmani Dan Olahraga Pada Lembaga Pendidikan di
Indonesia. Publikasi

Pendidikan 6(3).

Cahyani, Y. R. (2016). Pengaruh Aktivitas Olahraga dalam Pendidikan Jasmani Terhadap Tingkat Konsentrasi Belajar dan Prestasi Akademik di SMA Negeri 3 Bandung (Doctoral dissertation, Universitas Pendidikan Indonesia).

Ferdiyanto, F., Salim, F., Ajang, L., \& Lestari, A. (2019). Ubah Perilaku dengan Pendekatan Teori Pembelajaran Behaviouristik. Osf Preprint.

Guyton, A.C. (2012). Buku Ajar Fisiologi Kedokteran Edisi 11. Jakarta: EGC.

Mukhtar, R. (2015). Hubungan Motivasi Belajar dengan Hasil Belajar pada Mata Pelajaran Seni Budaya Bidang Seni Musik Siswa Kelas X SMA Piri 1 Yogyakarta. Skripsi Sarjana Tidak Diterbitkan. Yogyakarta: Fakultas Bahasa Dan Seni UNY [Universitas Negeri Yogyakarta].

Nasution, D.J. (2018). Hubungan Antara Motivasi Belajar dengan Konsentrasi Belajar Siswa. [Skripsi]. Padang: Universitas Negeri Padang.

Pratama, I. Y., Sinaga, J. L., \& Ompusunggu, H. E. S. (2017). Korelasi antara kadar hemoglobin dengan tingkat konsentrasi pada mahasiswa laki-laki Fakultas Kedokteran Universitas HKBP Nommensen Medan. Nommensen Journal of Medicine, 3(2), 58-62.

Sagareno, A.Z. (2020). Korelasi Adiksi Ponsel Pintar dengan Konsentrasi Belajar Mahasiswa Fakultas Kedokteran Universitas Lampung. [Skripsi]. Bandar Lampung: Universitas Lampung

Santoso, S. S., \& Anandaputra, H. (2017). Hubungan Intensitas Olahraga dengan Daya Konsentrasi Belajar Siswa/Siswi Kelas 10 dan 11 SMAN 5 Depok Jawa Barat. Jurnal Kedokteran dan Kesehatan, 13(1), 1-8.

Sardiman, A.M. (2016). Interaksi \& Motivasi Belajar Mengajar. Jakarta: PT RajaGrafindo Persada. 